Portland State University

PDXScholar

$11-2020$

\title{
Fire, Native Ecological Knowledge, and the Enduring Anthropogenic Landscapes of Yosemite Valley
}

\author{
Douglas Deur \\ Portland State University, deur@pdx.edu \\ Rochelle Bloom \\ Portland State University
}

Follow this and additional works at: https://pdxscholar.library.pdx.edu/anth_fac

Part of the Archaeological Anthropology Commons, and the Social and Cultural Anthropology Commons

Let us know how access to this document benefits you.

\section{Citation Details}

Deur, D., Bloom, R. (2020). Fire, Native Ecological Knowledge, and the Enduring Anthropogenic Landscapes of Yosemite Valley. In The Routledge Handbook of Indigenous Environmental Knowledge (pp. 126-135). Routledge.

This Book Chapter is brought to you for free and open access. It has been accepted for inclusion in Anthropology Faculty Publications and Presentations by an authorized administrator of PDXScholar. Please contact us if we can make this document more accessible: pdxscholar@pdx.edu. 


\title{
FIRE, NATIVE ECOLOGICAL KNOWLEDGE, AND THE ENDURING ANTHROPOGENIC LANDSCAPES OF YOSEMITE VALLEY
}

\author{
Douglas Deur and Rochelle Bloom
}

While recognized globally as an iconic natural landscape and the centerpiece of a pioneering national park, Yosemite Valley is in truth a place cultivated by generations of Native caretakers. Many Native peoples' homelands converge in Yosemite Valley - including Southern and Central Miwok, Northern and Owens Valley Paiute, Chukchansi Yokuts, and Western Mono tribal communities, linked to both the western Sierra Nevada slope and to the deserts to the east. This amalgam of tribal communities together actively shaped this landscape in myriad ways. Prior to Euro-American resettlement, seasonal, patterned burning transformed the plant communities of the entire valley, sustaining open grassy meadows and California black oak (Quercus kelloggii) groves in locations that would otherwise have been overgrown in subalpine conifer forests. This burning, in addition to other types of active management - selective harvesting, pruning, replanting, and many other techniques - produced signature anthropogenic plant communities that have long sustained the food, material, medicinal, and spiritual needs of Yosemite Valley's Native residents. In spite of a century and a half of active displacement, Native peoples and aspects of their management practices endure, as do clear traces of human stewardship of the lands and plant communities of Yosemite Valley. This chapter summarizes these interconnected historical, cultural, and biological developments with special attention to the specific mechanisms used by Native American managers of the landscape, and the implications for both tribes and park managers today.

In this context, Yosemite Valley is a place with rich and enduring traditions of Indigenous Ecological Knowledge, manifesting in specific management practices that, in turn, leave discernible imprints upon the natural landscape. Moreover, as one of the world's first national parks, and a destination of enduring global significance, Yosemite presents us with a uniquely rich corpus documenting this knowledge and its manifestations within Native American resource practices and within the environments and humanized landscapes of Yosemite Valley. 


\section{Background and methodology}

Our experience at Yosemite Valley demonstrates how IEK studies can be a highly productive historical and archival research endeavor, alongside ethnographic research with Indigenous Knowledge bearers. This is in part because documentation of Yosemite abounds within a nearly unbroken chronological succession of ethnographic, historical, agency, and travelers' accounts spanning the period from the mid-nineteenth century to the present. Today, the need to understand this knowledge and its implications has become relatively urgent. After a century and a half of fire suppression and other imposed changes, National Park Service staff confront rapid changes in Yosemite Valley vegetation, the decline of archetypal plant species and communities such as California black oak groves, the loss of iconic views to the encroachment of dense conifer stands, and a growing risk of catastrophic fire. These managers recognize that they must engage Indigenous Knowledge systems, and sometimes reintroduce Native management practices that extend from this knowledge - either by mimicking these traditions with modern analogues, or inviting Native harvesters back into the landscape to reestablish time-honored relationships between people and plants. With a growing sense of urgency, park managers recognize that Indigenous Ecological Knowledge is not a mere historical curiosity, but a living tradition that might yet provide compass points for future land and resource management for our common good.

In an attempt to understand the imprint of Indigenous Ecological Knowledge upon the Yosemite Valley landscape, we undertook certain research steps. Over a 15-year period, Deur carried out intermittent ethnographic interviewing and field visits with tribal members relating to traditional land and resource use (Deur 2007), following upon earlier ethnographic studies by researchers such as Bibby (1994) and Anderson (1988). Concurrently and in collaboration, drawing from the rich corpus of historical and ethnographic material relating to Yosemite Valley, Bloom oversaw the development of the Yosemite Ethnographic Database, which consists of roughly 12,800 individual entries describing traditional Native American use of Yosemite National Park lands and resources - the vast majority being within Yosemite Valley. Database entries incorporate data from a wide range of sources, including the Yosemite National Park Archives, the Yosemite Research Library, several university and museum collections, the California Digital Newspaper Collection, and numerous digital sources. National Council for Preservation Education (NCPE) interns working under the supervision of Bloom and Deur compiled and entered the assembled data from over 575 sources. This includes data derived from historical reports, early historical accounts written by visitors to Yosemite, ethnographies, ethno-ecological studies, Yosemite Nature Notes, oral histories, park notes from contemporary tribal events, archival materials, historical and contemporary newspaper articles, and more. These were supplemented with other materials, such as notes from tribal consultation meetings with park-associated tribes, and meetings with these tribes specifically on matters of traditional plant community management.

The resulting database provides a resource of rare detail and comprehensiveness, containing the vast majority of the written corpus regarding Native American communities' relationships to the Yosemite landscape across time. The database has become a tool for park managers seeking to understand the traditional uses of particular lands and resources within Yosemite, when used alongside their regular communications with contemporary park-associated tribal members. And this database has become a powerful tool for park-associated tribes attempting to document and understand their own practices in this unique montane environment. As a research tool, the database has allowed the authors to identify nearly all reported traditional land management practices employed by tribes both historically and today, through repeated 
and mutually reinforcing references in tribal oral accounts, written historical accounts, and other documentation. The picture provided by these combined accounts coheres with the findings of allied disciplines relating to Yosemite vegetation history and Yosemite Valley archaeology (Gassaway 2005, 2009; Gibbens and Heady 1964; Heady and Zinke 1978), while also illuminating working hypotheses for future vegetation and archeological studies. In the pages that follow, we summarize the specific forms of traditional resource management identified through this analysis.

\section{Methods of traditional management in Yosemite Valley}

Historically, and to a much lesser extent today, the Native American inhabitants of Yosemite Valley have employed a variety of techniques that materially enhance the availability of culturally preferred plant communities. While similar to other practices documented in California and the Great Basin, these techniques were uniquely adapted to fit the opportunities and constraints of the subalpine zone. Here, we identify specific techniques that appear consistently in the oral traditions and written historical accounts of the valley. These methods included anthropogenic burning, pruning and coppicing, clearing underbrush beneath trees, hand eradication ("weeding") of certain competing species, selective harvesting, smoking, "knocking" of dead wood from the tree, and other practices associated with both mundane activities and the spiritual beliefs of tribal communities traditionally associated with Yosemite.

\section{Burning}

Native peoples traditionally employed anthropogenic burning to clearYosemite Valley of underbrush and maintain an open landscape (Commissioners to Manage the Yosemite Valley and the Mariposa Big Tree Grove 1891-92: 6-7; Ernst 1949:40). The fire regime in this region historically involved frequent, low-intensity surface fires set in a rotation to create a dynamic mosaic of plant communities in different stages of succession. Burns varied in size from localized spot fires, impacting only specific patches of plants, to clearing burns covering much larger areas (Gassaway 2009: 10; Taylor 2006: 9). Burning typically occurred in the fall after a few rains, with fires set at one- to several-year intervals (Anderson and Moratto 1996: 197-198).

Regular burning in the valley was guided by systems of Indigenous Ecological Knowledge pertaining to the timing of fires, as well as their location, required weather conditions, requisite scales, ignition points, and myriad other considerations. In turn, burning-guided by this understanding of fire, situated in place and accumulated knowledge across generationscreated a variety of outcomes, including the production of culturally preferred plant communities that fostered Native sustenance, and other needs of Native communities. Burning promoted the dominance of certain plant species such as the black oak that were particularly suited to low-intensity surface fires, clearing competing vegetation and facilitating the germination and succession of new trees (Kuhn and Johnson 2008: 4; Reynolds 1959). Burning also stimulated the growth of several other culturally preferred plant species, caused the release of nutrients from accumulated biomass, and triggered the germination of fire- and heat-stimulated seeds (Anderson and Rosenthal 2015: 21; Reynolds 1959: 159-160; Stewart 2002: 294). Furthermore, Elders note that burning encouraged certain shrub species to regrow straighter stems following a fire, which produced high quality materials for producing baskets, spears, harpoons, canes, and a variety of other items (Anderson and Rosenthal 2015: 20, 24; Wickstrom 1987: 9).Vegetation in certain stages of regrowth after a fire were also ideal habitats for animals-producing forage and cover for the likes of mule deer, black-tailed jackrabbits, 
dusky-footed woodrats, California quail, greater roadrunners, and turkey vultures - all used for some combination of meat, furs, and feathers by Native peoples (Anderson 1988: 141; Anderson and Rosenthal 2015: 21, 24).

Burning created additional habitat-scale benefits as well. By producing clearings and creating a park-like open space in the meadows of Yosemite Valley, burning made acorn collection easier, eliminated hiding places for enemies, and reduced conifer encroachment on oaks, which thrive in open spaces (Grom and Camp 1959; Kuhn and Johnson 2008: 4; Martin 1996). Additionally, regular and systematic burning had the effect of reducing destructive wildfires by eliminating fuels such as underbrush, dead leaves, pine needles, and other debris (Bigelow 1904: 8; Kuhn and Johnson 2008: 4; Stoy 1890: 26) and assisted in controlling pests and pathogens that plagued some culturally preferred plant and animal species (Anderson and Rosenthal 2015: 22; Kuhn and Johnson 2008: 4). Burning may have limited the spread of root fungus, in part by keeping trees scattered and isolating the disease (Champion 1986; West 1986:2). Brush-burning also may have increased the availability of surface water and increased the flow of springs by reducing water uptake from less culturally significant shrub and tree species, while reducing moisture stress for those culturally preferred species that remained after repeat burning (Anderson and Rosenthal 2015: 22; Wickstrom 1987: 8).

\section{Smoking}

Exposure of plants to smoke, a byproduct of anthropogenic burning, provided ancillary benefits to culturally important plants, and represented an important and sometimes independent traditional management technique. Traditionally significant plants like chia, red mains, bluehead gilia, caterpillar Phacelia, and coyote tobacco (Nicotiana attenuata S. Watson) depend on exposure to smoke or charred wood for germination (Anderson and Rosenthal 2015: 15). A reported additional benefit of smoke is the decrease of insects that live and feed on food plants like sourberry, and ostensibly many others (ibid.: 22). Native consultants also share that smoke benefits the health of black oaks, contributing to increased acorn production (Anderson 1993: 189; Goode 2014: 6). Though references to this practice in Yosemite are few, Elders suggest that smoking may have been among many benefits of burning for the Yosemite Valley flora.

\section{Pruning}

Native peoples have traditionally pruned the ends of oak branches, allowing them to gather acorns early in the season before they were ripe enough to fall (Clark 1894: 15; NPS 2016b: 4). Particularly with oaks, pruning removes diseased limbs from trees and makes branches less likely to be broken by heavy winter snows or to combust during fires to the detriment of living trees (Clark 1894: 15; NPS 2014: 2). Pruning the tips of oak branches also encourages the growth of new branches and stimulates production of acorns (Anderson 2005: 139; Long et al. 2016: 63). Similarly, traditional harvesters have pruned other species, such as elderberry and manzanita, cutting off the flower or fruit-bearing portion of the branches to facilitate the growth of multiple fruiting stems (Anderson 1988: 132). Some sources suggest that pruning the tips of plants sustains the health, growth, and productivity of the plants generally, beyond the production of fruit- and flower-bearing stems (Anderson 2005: 139, 173; Stevens 1998: 31-32). Harvesters also prune various other plants, such as redbud, sourberry, and willow close to the ground or stem base, in order to produce the long, straight shoots ideal for use in basketry (Anderson 1988: 133; 2005: 319; Bates 1997; McCarthy n.d.: 26, 40). 


\section{Clearing underbrush}

Individuals, families, and communities have traditionally raked leaf litter and cleared the ground around certain culturally preferred plant communities-especially black oak groves (Anderson 1988: 215; Bibby 1994: 57). This made access to culturally preferred plant species easier, while also serving to remove the buildup of underbrush and reduce potential competition and crowding by less prioritized species (Anderson 1988: 164-165). This practice also eliminated ladder fuels, reducing the odds of catastrophic fires that might harm culturally significant plant communities, especially black oak groves. Some attempt to remove sticks, litter, and underbrush has continued into modern times, being undertaken clandestinely or otherwise by Native harvesters, especially in black oak groves and other places where community harvests and investment are most concentrated.

\section{Hand eradication}

Native harvesters have often weeded competing plants from patches of culturally preferred species, or have engaged in the hand-removal of young trees in combination with anthropogenic burning to control brush and tree growth. Galen Clark (1894: 14-15) writes of Native harvesters he observed in the nineteenth century: "When the fires did not thoroughly burn over the moist meadows, all the young willows and cottonwoods were pulled by hand." Native peoples also weeded to clear the ground and improve gathering potentials (Bibby 1994: 57). Similar to the effects of clearing underbrush, weeding reduced the potential for competition among different plants and the crowding out of preferred plants (Anderson 1988: 164-165). Additionally, clearing underbrush and maintaining open meadows eliminated ladder fuels and reduced the likelihood of destructive crown fires, promoting light surface fires that only burned undergrowth while leaving oak groves and other preferred habitats relatively untouched (Martin 1996). This tradition of weeding competing species such as conifer trees has persisted, sometimes with NPS involvement and sometimes not, to protect culturally significant plant communities such as black oak groves.

\section{Selective harvesting}

Tribal members have often practiced selective harvesting, leaving parts of various tubers, bulbs, corms, rhizomes, and mushrooms within the soil when they harvested, so that remaining plants could regenerate (Anderson 1993: 93; 2005: 299; Anderson and Lake 2013: 58). Additionally, harvesters gather only the largest mushrooms, leaving smaller mushrooms to ensure the health and dispersal of culturally preferred mushroom species (Anderson 2005: 299; Anderson and Lake 2013: 58). Elders suggest that these practices are ancient, long predating Euro-American contact and calibrated by their long-term experiences as a community with plant resource abundance and scarcity. These selective harvesting traditions ensure that culturally significant plant communities will not be overexploited. Some suggest that selective harvesting may also preserve the genetic diversity of the species in various ways, such as by moderating the effects of human harvesters on the reproductive success of plant populations with distinctive and desirable genetic traits (Anderson and Lake 2013: 58).

\section{Soil aeration}

Harvesters loosened the earth in meadows as they dug edible bulbs with digging sticks, which also functioned to aerate the soil, reduce soil compaction, encourage bioactivity, and allow 
water to percolate deeper into drier soils (Anderson 2005: 173; Reynolds 1959: 189-190; Stevens 1998: 31-32). Together, these effects facilitate the development of larger and more numerous edible bulbs, the straighter growth of underground stems used for basketry, and the like. Systematic studies demonstrate that these traditional methods stimulate the growth of bulbs-working humus into the soil column, accelerating biotic action, improving aeration and decomposer access, and through other mechanisms (Anderson 2005: 173; Ortiz 1991: 5).

\section{Knocking}

"Knocking" is a management technique that occurs in conjunction with traditional gathering. Elders describe it as "a kind of massage for the tree, to give it energy and continue the relationship between the harvester and the tree" (Goode 2014: 6). Gatherers use knocking sticks to assist with removal of acorns from higher branches that cannot be reached from the ground, which encourages acorns to fall without damaging branches or bark (Anderson 1993: 174-175, 208; 2005: 141; Long et al. 2016: 44; NPS 2016c: 3). While knocking off acorns, or knocking trees generally, gatherers also successfully remove dead and diseased wood from the trees; in turn, this reduces the likelihood of disease or catastrophic fire that might affect the living tree, while also stimulating new growth (Martin 1996). Only healthier branches, with live and healthy cambium beneath the bark, remain after a thorough knocking. As one Native consultant explained, "Knocking wakes up the tree" (NPS 2014: 2).

\section{Sowing}

While detailed documentation is unavailable for Yosemite Valley, documentation regarding tribes associated with Yosemite shows that they also actively sowed certain plant propagules, most notably tobacco, by scattering seeds and scratching the ground with a stick in well-watered and burnt-over ground. People especially cultivated certain well-watered northern slopes or the inside of a burnt, rotten log to reduce moisture stress (Anderson 1988: 135; Barrett and Gifford 1933: 194). Accounts suggest that, through such practices, the tobacco grown in plots managed with these methods produced larger leaves and better flavor than untended or casually tended plots. Selective gathering and sowing enhanced these desired characteristics and provided valley residents with a regular supply of tobacco for use or trade (Anderson 1988: 160; Barrett and Gifford 1933:1 94).

\section{Other methods and considerations}

Tribal members today consistently stress the holistic nature of landscape management, and the ways in which management for one resource is inseparable from the management of whole ecosystems on the valley floor. As a consultant explained, "Native people did not manage one thing, they managed the whole landscape" (NPS 2016d: 3). Another consultant stressed the need to "look at the big picture. We gather the acorns, we hunt the deer. It's all connected" (NPS 2016b: 3). The various management techniques_-gathering, hunting, and other ways of interacting with landscape, all contribute to ensuring the health of plants, animals, people, and the land (NPS 2014: 1; 2016d: 2).

Elders also report that, traditionally, the spiritual relationship and sense of interconnectedness between tribal members and culturally significant plant communities are also an essential part of sustaining the wellbeing of plants (NPS 2014: 1). Beyond mechanical management methods, harvesters sustain the relationship between plants and people through singing, dancing, and 
talking to plants and entire plant communities (NPS 2016b: 2). Traditional harvesters have understood that "giving thanks to the oak tree and other plants is essential for the continued health of the plant, and to the people who utilize the resource" (NFR 2019: 11). Even today, tribes hold acorn festivals to show thanks and ritually intervene to ensure the abundance of acorns. This is shaped, in part, by certain beliefs regarding the first acorn crop-for example, beliefs about how burning will affect fertility and about the importance of sharing some part of the harvest with animals (Deur 2007: 58; Moore 1985: 20; NPS 2014: 1). Each of these practices has certain material manifestations, such as leaving behind acorns for squirrels to cache and effectively replant, that unambiguously enhance plant output. Moreover, tribal members assert that showing such respects enhances plant output in ways that, as yet, defy the comprehension and methods of Western science.

\section{The displacement of Native peoples and Native landscapes}

The advent of Euro-American settlement in Yosemite Valley in the 1850s and 1860s greatly affected Native lifeways in Yosemite Valley. The removal of Native people from the valley and the suppression of fire and other traditional practices undermined both the integrity of the human communities and the biotic communities with which they were interdependent. EuroAmericans first entered Yosemite Valley in 1851 as part of the Mariposa Battalion, a militia unit formed to fight the Yosemite and Chowchilla Indians in the Mariposa War-one of many anti-Indian campaigns undertaken in the first years following the advent of the California Gold Rush and American occupation of California. The next several years were marked by interethnic hostilities, as an expanding population of Euro-American settlers entered the valley and lands adjacent. The astonishing scenery of the valley gained almost instant national attention. Tourism and settlement in Yosemite Valley began almost immediately after the first entry of the Mariposa Battalion. James Mason Hutchings had begun leading tourist parties into Yosemite Valley by 1855, while permanent Euro-American settlement of the valley began in 1859 (Greene 1987). The changes introduced by these developments quickly and dramatically impacted Native habitation patterns and traditional practices.

By 1864, a mere 13 years after the Mariposa Battalion first glimpsed the valley, U.S. Congress passed the Yosemite Park Act. This Act formally transferred Yosemite Valley and the Mariposa Grove of giant sequoias (Sequoiadendron giganteum) -including some of the largest trees on Earth - to the State of California under the management of a state board of commissioners. In 1890, the U.S. Congress designated the area surrounding Yosemite Valley and Mariposa Grove as a national park, initially administered by the U.S. Army. In 1906, a congressional act formally returned the valley and grove to the management of the federal government (Mancillas 2000: 5-7). Predating the development of the United States' National Park Service by a full ten years, this was a foundational park and served as a precedent for other national parks around the world.

These developments compelled many Native people to relocate among neighboring tribes. The NPS gradually consolidated those who remained into increasingly circumscribed areas with tightening limitations on who the agency permitted to remain (Mancillas 2000: 3). By the first decade of the twentieth century, Native families in Yosemite Valley were restricted to a single village site. When 1930s' Park Service regulations demanded reduced numbers of Indians in the park, the agency determined that some possessed a "moral right" to remain, and then removed the rest. The agency destroyed the one remaining village to allow for the construction of a park medical clinic, and relocated remaining residents to the "New Village," near the site of the historic village of Wahogah (Bibby 1994: 112; Greene 1987: 9). In 1953, the park 
adopted the Yosemite Indian Village Housing Policy, which called for the gradual eviction of all remaining Indians from the park (Mancillas 2000: 5-7). The NPS officially terminated the final Indian village in 1969, razing cabins in turn, as their residents lost their seasonal or fulltime jobs in the park. Those who remained employed by the park were allowed temporary housing in other areas until they retired and were evicted-a process that continued through the 1990s. Even today, in communities surrounding the park, many tribal members recall residing in Yosemite Valley for decades of their younger lives (Bibby 1994: 113; George 2017; Spence 1999; Turek and Keller 1998).

\section{Impacts on traditional management, cultural practices, and IEK}

Alongside the physical displacement of Native peoples, traditional resource management was also limited or prevented - undermining myriad cultural, dietary, social, and economic practices of tribes while also negatively impacting the health and fecundity of the species under their care (Deur and James 2020). The traditional management practices described in this chapter entered a sharp decline immediately upon the entry of non-Native settlers and park managers into the valley. Under the period of state control (1864-1890), authorities sought to suppress fires and prohibited traditional burning; enforcement, however, was often disorganized and intermittent. Beginning in 1890, when Yosemite became a national park, federal troops served to aggressively suppress fires and police Native land managers under a host of new regulations (Rothman 2005: 16-19; Taylor 2006: 2). The last officially recorded instances of burning conducted by Yosemite's Native inhabitants occurred in the late nineteenth century (Ernst 1943: 59; YNP 2010: III-109). Meanwhile, official park reports documented the encroachment of brush and conifer trees, along with the loss of key vistas, as early as the 1870s as an outcome of emerging park restrictions on Native burning (Briggs 1882: 10-11; Gibbens and Heady 1964: 11). The Report of the Commissioners to Manage the Yosemite Valley and the Mariposa Big Tree Grove (1891-92: 6-7) detailed the changes to the valley following the suppression of anthropogenic burning and other traditional management practices:

$[T]$ he valley originally was a forest park, dotted with open meadows. Its Indian owners kept the floor clear of underbrush. It is known that besides the careful use of fire for this purpose they annually pulled up unnecessary shrubs and trees as soon as they sprouted. This protected the large trees from destruction by fire and left a free view of the walls, waterfalls, and beauties of the valley. Letting nature have her way in choking every vista with underbrush has obscured many of the finest views, has hastened the destruction of many fine old trees, especially the oaks, which, when crowded and starved by younger growth, yield to parasites and decay, and has increased the risk from fire.

In subsequent decades, writers and researchers continued to record the deteriorating landscape conditions characterized by diminishing meadows, conifer encroachment, deteriorating quantity and quality of native plant species, and obscured vistas (Ernst 1949; Gibbens and Heady 1964; Storer and Usinger 1963: 35). As Native harvesters sought to respond to these conditions, indications suggest that burning continued intermittently and on a small scale, beyond the gaze of park managers, in the less-developed areas on the edges of the valley into the early twentieth century (Gassaway 2005: 117; Deur 2007).

The redevelopment of the valley to accommodate tourist development only compounded these effects. In 1879, Galen Clark, Guardian for the State of California Yosemite Grant, blasted 
the El Capitan moraine in an attempt to reduce flooding, in order to facilitate visitor access to Yosemite Valley and enable agricultural use of the valley floor (Clark 1904: 396; Deur 2007: 52; Gibbens and Heady 1964: 15-17; Huber and Snyder 2007: 107-109). Historically, the moraine and the rock obstruction below Mirror Lake on Tenaya Creek served as rock barriers and contributed to the wetland hydrology of the valley floor (Deur 2007: 51-52; Matthes 1930). Researchers argue that the blasting of the moraine resulted in lowering the water table and, as a result, decreased seasonal flooding within the low riparian meadows (Huber and Snyder 2007: 107-109; Milestone 1978). Moreover, through much of the early twentieth century, park staff made other hydrological "improvements"-dredging and revetment of the Merced River, dredging sand from Mirror Lake, filling and developing wetlands, ditch construction in meadows to route pedestrian tourists, the removal of beaver dams and logjams, and other forms of flood control (Deur 2007: 52-53; Gibbens and Heady 1964: 5; Milestone 1978).

Together with fire suppression, these effects accelerated conifer encroachment into anthropogenic habitats of enduring concern to Native harvesters (Deur 2007). These changes diminished the size of riparian wetlands and seasonally-flooded meadows in Yosemite Valley and reduced the availability of culturally preferred species found disproportionately in these habitats (ibid.: 51-52). The lowered water table is cited as one of the primary explanations for the death of oak trees and the decrease in the number of acorns, as well as the encroachment of non-native invasive species into these increasingly dry meadow environments (NPS 2016c; Yosemite National Park 2011: 45). Riverine downcutting and bank hardening have also dramatically decreased the scale of alluvial sand deposits where the best fern and sedge roots for basketry grow (Deur 2007: 30, 53-54).

Several other practices associated with non-Native settlement, development, and tourism also contributed to the erosion of Yosemite Valley vegetation and soil. As early as 1851, with the entry of the Mariposa Battalion, livestock grazing began in Yosemite Valley. It steadily increased in the ensuing decades alongside the rise in settlers and, in time, park and concessionaires' livestock herds in support of tourist operations. Though grazing gradually declined as automobile use increased, and though it was discontinued in 1933, the practice had long-term impacts on the soil and vegetation of the valley. Livestock cropped, pulled, and trampled finer grasses; coarser ones remained and flourished. Compaction of the soil and subsoil within meadows obstructed the percolation of water, undermining the effects of traditional soil aeration by Native harvesters, causing soils to dry out faster (Gibbens and Heady 1964: 15). These changes created an environment favorable to the establishment of introduced species, as well as young conifers and woody shrubs in former meadows and riparian margins, while making it more difficult for certain culturally preferred native species to thrive (ibid.: 25).

Activities of park visitors have also contributed to the deterioration of certain plant species and the decline in traditional plant use in Yosemite Valley (Deur 2007: 56). The number of visitors to the park has increased exponentially over the decades. In 1906, the year that the federal government assumed management of Yosemite Valley, park managers recorded only 5,414 visitors. Visitation has increased almost inexorably ever since. By the 1990 s, annual visitor numbers had already reached more than 4,000,000; the total exceeded 5,000,000 for the first time in 2016 (NPS 2019).Visitor foot traffic through meadows and oak groves has created damaging social trails, while picnicking, camping, and other activities have harmed native vegetation while also displacing remaining Native harvesters from time-honored gathering sites (Deur 2007: 53, 56; Gibbens and Heady 1964: 5, 15; Rothman 2005: 17). Visitors reportedly take acorns as souvenirs, which, over time, not only reduces available acorns for Native harvesters, but also reduces seedling recruitment in black oak groves (NPS 2016b). Similar small-scale picking or gathering of other plant materials by visitors also incrementally affects 
vegetation and reduces gathering opportunities for tribal members in heavily visited portions of the park. Moreover, tribal members suggest that the rising number of tourists and increasing park traffic have resulted in worsening pollution that adversely affects the health of gatherers, plants, and those who consume plants from the valley (NPS 2016a; 2016b; 2016c; Vasquez 2019: 33). Consultants describe concerns that the construction of the park infrastructure-such as road development, sewer lines, lawn maintenance, and possible soil contamination resulting from past park development - has also adversely impacted plant species (Anderson 2005: 321; NPS 2016d). Herbicides that the park sprays on invasive plant species, some harvesters suggest, also put gatherers at risk of health issues (Pfeiffer and Ortiz 2007).

Tribal members assert that the large number of visitors to Yosemite Valley results in crowds in and around traditional gathering areas. This undermines gathering and plant management activities that tribes traditionally carry out privately (Deur 2007: 15). Tribal consultants note that while some visitors are supportive of traditional gathering, they frequently ask questions, make comments, take photographs, or report activities to park employees when they are perceived to violate park rules (ibid.: 56).Visitors, in effect, continue to provide unwelcome surveillance and policing of Native activities, even when NPS policy has become more open to traditional management and harvests. Tribal members also commonly report feeling "like a tourist attraction" while trying to carry out culturally significant harvests in the valley. This is a challenge not only to the mechanics of plant gathering and management, but also undermines the ceremonial aspects of plant gathering, which are integral to the practice. In response, most tribal members who gather plants in Yosemite Valley make efforts to gather in locations not frequented by visitors, or at times when they are not present. As a result, the timing and locations of gathering have changed, becoming more dynamic and diffuse (Deur 2007; NPS 2016b, 2016c).

Native Elders generally agree that the effects on Yosemite Valley's anthropogenic landscapes have been dire. Black oak recruitment has diminished dramatically; undergrowth and competing species have quickly overtaken the groves; and riparian meadows, once characterized by a high degree of biodiversity and a mosaic of different plants, are increasingly supplanted by relatively uniform stands of conifers. In 2009, echoing the official findings of the park commissioners some 118 years prior,Yosemite National Park staff inventoried 181 scenic vistas and found that vegetation encroachment resulting from park policies had "completely obscured about onethird of the vistas, and partially obscured over half the vistas" (YNP 2010: vii). Consequently, the forcible elimination of Native harvesting and management from Yosemite Valley has had an adverse impact on more than Native peoples; the elimination of longstanding Native knowledge and practice from this landscape has served to erode the very same natural landscapes that park founders sought to protect through the creation of one of the world's most prominent national parks.

\section{Yosemite's anthropogenic landscapes today}

Today, certain keystone plant communities persist in diminished form on the landscape, such as in black oak groves, despite a century and a half of dramatic change. Such anthropogenic landscapes remain a potent locus of cultural meaning to modern tribes, and a focal point of ongoing National Park Service efforts to sustain these unique landscapes-managed with a growing recognition not only of their biological value, but also of their role as keystone cultural landscapes shaped by countless generations of Native knowledge-holders. The park currently conducts consultation and partners with seven tribes and tribal organizations with ancestral ties to Yosemite who continue to maintain connections to park lands and resources: the American Indian Council of Mariposa County (Southern Sierra Miwuk Nation); the North 
Fork Mono Rancheria; the Tuolumne Band of Me-Wuk Indians; the Picayune Rancheria of Chukchansi Indians; the Mono Lake Kutzadika'a Tribe; the Bridgeport Paiute Indian Colony; and the Bishop Paiute Tribe. Together, these tribes and organizations continue to recount the Indigenous Ecological Knowledge of their ancestors and its implications for the past, present, and future management of Yosemite Valley landscapes. In recent consultation meetings and shared planning efforts, these descendants of Yosemite's original caretakers stress the importance of reintroducing the traditional management activities integral to caring for their ancestral land and maintaining the integrity of its natural and cultural landscapes (BIC 2019: 94-95; BPT 2019: 202; NFR 2019: 7; SSM-AICMC 2019).

The NPS has increasingly sought to incorporate Indigenous Ecological Knowledge and specific management practices (or their analogues) into modern land and resource management planning for Yosemite Valley. In recent years, the park has invited participation by tribal members in conducting prescribed burns, reintroducing regular fires to the valley floor (Kinoshita 2008). Within park natural resource planning, there has been growing and explicit acknowledgment of the role of Yosemite's traditional Native residents in the shaping of Yosemite Valley's landscape, vistas, habitats, and species composition. As such, management plans such as the Merced River Plan (YNP 2014) and the Yosemite Valley Scenic Vista Management Plan (YNP 2010) specifically acknowledge the contributions of Indigenous Ecological Knowledge to the landscape.

In this context, the authors have directed a multi-year effort to develop background documentation and monitoring protocols, addressing both cultural and culturally salient biological criteria in support of Merced River planning. As mandated by NPS policy and decisions in U.S. courts, Yosemite National Park must now assess California black oak as "ethnographic resources" that require protection and enhancement by virtue of their cultural significance. Together, we have developed protocols that incorporate Indigenous Ecological Knowledge and management strategies, using metrics to assess the integrity of these resources based on both biological and cultural criteria. As the NPS implements these protocols, Yosemite's anthropogenic plant communities will be increasingly monitored and brought into line with criteria reflecting the knowledge of many generations of Native land managers (Deur and Bloom 2018a; 2018b; 2018c).

In sum, Native peoples associated with Yosemite Valley have long practiced a range of traditional management techniques, contributing to a natural environment in which culturally preferred species thrived. Various methods such as burning, pruning and coppicing, clearing underbrush, weeding, selective harvesting, smoking, and "knocking" sustained traditional subsistence practices and fulfilled the caretaking responsibilities mandated by the Creator within Native oral tradition. Tribal members today explain that they "have been commissioned from the first time of our existence to be stewards of the land, knowing that this is how we will survive" (NFR 2019: 13). The techniques associated with this calling promoted the dominance of preferred species for use as food, medicines, and materials, improved the quantity and quality of species produced, produced open vistas, and decreased the threat of pests, pathogens, and conflagration. Indigenous Ecological Knowledge, and the management practices implied by this knowledge, created the park-like conditions of the valley as first encountered by EuroAmericans. This was no mere "wilderness" encountered by the likes of the Mariposa Battalion, but a fully humanized landscape — cultivated and under constant care -manifesting the longheld knowledge and the deepest cultural values of resident peoples, clearly inscribed upon the landscape.

The displacement of Native peoples has dramatically and adversely impacted both Native communities and the landscape of the valley and plant communities with which they are connected. In recent years, however, the National Park Service and the public at large have 
come to accept that the concept of a Yosemite "wilderness" was largely an invention of the Western mind. Conservation, as conceived by this classic model, was integral to the theme of Native displacement, as has been true in so many places around the world (Dowie 2009). To continue to embrace this fiction would be to court disaster in both cultural and natural domains.

Accordingly, the NPS has increasingly recognized the need to reintroduce traditional management values and methods to this contested landscape. Yosemite has begun incorporating the traditional practices of its first inhabitants into its management of the landscape, consulting with traditionally associated tribes, and welcoming their participation in unprecedented ways. In spite of this progress, the continuing decline in quantity and quality of keystone plant habitats and species indicates that more work lies ahead. Multidisciplinary research, cross-cultural dialogue, and management actions will be required if the anthropogenic landscapes of Yosemite Valley, and the people who long sustained them, will continue to thrive into the foreseeable future. The often painful lessons of the Yosemite experience provide a cautionary tale for other parks and protected areas that seek to remove or materially affect the activities of Native peoples within their boundaries in pursuit of conservation goals-especially when those Native peoples have been integral to the very natural order these parklands are meant to protect. So too, recent responses by the National Park Service, such as ambitious programs for tribal research and engagement, may be important touchstones for other parks and protected areas nationwide. Much as Yosemite National Park was pioneering as an early experiment in national park creation, so its modern engagement with tribes — carried out with varying degrees of success, with unusually high levels of national and international scrutiny-might also illuminate tentative new paths forward in the protection of the world's most spectacular and sensitive natural areas.

\section{References}

Anderson, M. K. 1988. Southern Sierra Miwok Plant Resource Use and Management of the Yosemite Region: A Study of the Biological and Cultural Bases for Plant Gathering, Field Horticulture, and Anthropogenic Impacts on Sierra Vegetation. Unpublished Master's thesis, Department of Wildland Resource Science, University of California, Berkeley.

Anderson, M. K. 1993. Indian fire-based management in the sequoia-mixed conifer forests of the Central and Southern Sierra Nevada. Report submitted to Yosemite Research Center, Yosemite National Park.

Anderson, M. K. 2005. Tending the Wild: Native American Knowledge and the Management of California's Natural Resources. Berkeley, CA: University of California Press.

Anderson, M. K. and F. K. Lake. 2013. California Indian ethnomycology and associated forest management. Journal of Ethnobiology 33(1): 33-85.

Anderson, M. K. and M. J. Moratto. 1996. Native American land-use practices and ecological impacts. In Sierra Nevada Ecosystem Project: Final Report to Congress, Assessments and Scientific Basis for Management Options, Vol. II. Davis:, CA: University of California, Centers for Water and Wildland Resources, pp. 187-206.

Anderson, M. K. and J. Rosenthal. 2015. An ethnobiological approach to reconstructing indigenous fire regimes in the foothill chaparral of the Western Sierra Nevada. Journal of Ethnobiology 35(1): 4-36.

Barrett, S. A. and E. W. Gifford. 1933. Miwok material culture: Indian life of the Yosemite region. Bulletin of Milwaukee Public Museum 2(4): 117-376.

Bates, C. 1997. Memo on traditional gathering areas in El Portal, Jan. 12. On file, Anthropology Office, RMS, Yosemite National Park, El Portal, CA.

Bibby, B. 1994. An ethnographic evaluation of Yosemite Valley: The Native American cultural landscape. Manuscript on file, Department of Anthropology, Yosemite National Park.

BIC (Bridgeport Indian Colony). 2019. Bridgeport Yosemite Paiutes: Who we are. In Voices of the People: The Traditionally Associated Tribes of Yosemite National Park. El Portal, CA: National Park Service, Yosemite National Park, pp. 177-213.

Bigelow, J., Jr., Maj. 1904. Report of the Acting Superintendent of Yosemite National Park in California to Secretary of the Interior. In Annual Reports of the Department of the Interior for the Fiscal Year Ended 
June 30, 1904. (Box 979.447Y-11 [“Reports of Superintendents"], No Folder).Yosemite National Park Research Library. Washington, DC: Government Printing Office.

BPT (Bishop Paiute Tribe). 2019. Manahu. In Voices of the People: The Traditionally Associated Tribes of Yosemite National Park. El Portal, CA: National Park Service, Yosemite National Park, pp. 187-206.

Briggs, M. C. 1882. Report of the Commissioners to Manage the Yosemite Valley and the Mariposa Big Tree Grove. In Biennial Report of the Commissioners to Manage the Yosemite Valley and the Mariposa Big Tree Grove, so extended as to include All Transactions of the Commission from April 19, 1880, to December 18, 1882. Sacramento: State Office, J.D. Young, Supt. State Printing.

Champion, D. 1986. Disease threatens to kill all of Yosemite's evergreens. San Francisco Chronicle, 18 October.

Clark, G. 1894. Letter to the Hon. Board of Commissioners of the Yosemite Valley and Mariposa Big Trees Grove. Folder 68, Box 2, Craig Bates Collection. El Portal, CA: Yosemite Archives.

Clark, G. 1904. Indians of the Yosemite Valley and Vicinity: Their History, Customs, and Traditions. Yosemite Valley, California: G. Clark.

Commissioners to Manage the Yosemite Valley and the Mariposa Big Tree Grove. 1891-1892. Biennial Report of the Commissioners to Manage the Yosemite Valley and the Mariposa Big Tree Grove for the Years 1891-92. Reports of the Commissioners to Manage the Yosemite Valley and the Mariposa Big Tree Grove for the Years, Biennial Reports 1889-1904-1888. State Office, Sacramento. On File, Resources Management and Science Library, El Portal, CA.

Deur, D. 2007. Yosemite National Park Traditional Use Study: Plant Use in Yosemite Valley and El Portal. Pacific West Social Science Series No. 2007-001. Seattle, WA: USDI National Park Service.

Deur, D. and R. Bloom. 2018a. A Review and Assessment of Ethnographic ORV Standards, Indicators, and Monitoring Protocols: Yosemite Valley, Yosemite National Park. El Portal, CA, and Seattle,WA: USDI National Park Service,Yosemite National Park and Pacific Northwest CESU.

Deur, D. and R. Bloom. 2018b. Yosemite Valley Traditional Use Plant Inventory and Threat Assessment: Yosemite Valley, Yosemite National Park. El Portal, CA and Seattle, WA: USDI NPS, Yosemite National Park and Pacific Northwest CESU.

Deur, D. and R. Bloom. 2018c. Black Oak Monitoring Protocols for the Merced Wild and Scenic River Ethnographic ORV.El Portal, CA, and Seattle,WA: USDI NPS,Yosemite National Park and Pacific Northwest CESU.

Deur, D. and J. E. James, Jr. 2020. Cultivating the imagined wilderness: Contested Native American plantgathering traditions in America's national parks. In N.J.Turner (Ed.), Plants, People, and Places: The Roles of Ethnobotany and Ethnoecology in Indigenous Peoples' Land Rights in Canada and Beyond. Montreal: McGillQueens University Press.

Dowie, M. 2009. Conservation Refugees: The Hundred-Year Conflict between Global Conservation and Native Peoples. Cambridge, MA: MIT Press.

Ernst, E. 1943. Preliminary Report on the Study of the Meadows of Yosemite Valley. Unpublished Report. File No. 880-01.Yosemite National Park, CA. United States Department of the Interior, National Park Service.

Ernst, E. 1949.Vanishing meadows in Yosemite Valley. Yosemite Nature Notes 28(5): 34-40.

Gassaway, L. 2005. Hujpu-St: Spatial and Temporal Patterns of Anthropogenic Fire in Yosemite Valley. MA thesis, Anthropology/Archaeology, San Francisco State University, San Francisco, California.

Gassaway, L. 2009. Native American fire patterns in Yosemite Valley: Archaeology, dendrochronology, subsistence, and culture change in the Sierra Nevada. SCA Proceedings 22.

George, C. 2017. Decades after it was destroyed,Yosemite's last Native American village is returning. Fresno Bee, 15 December.

Gibbens, R. F. and H. F. Heady. 1964. The influence of modern man on the vegetation of Yosemite Valley. California Agricultural Experiment Station, Manual 36. University of California, Division of Agricultural Sciences.

Goode, R.2014.Cultural burn.Tribal Chair North Fork Mono.Paper Presented to the Dinkey Collaborative, Dinkey Creek, California. On File,Yosemite National Park, RMS, Department of Anthropology.

Greene, L.W. 1987. Yosemite: The Park and its Resources: A History of the Discovery, Management, and Physical Development of Yosemite National Park, California. Denver, CO: National Park Service. Historic Resource Study series. Printed by Government Printing Office, Denver, 3 vols.

Grom, B. and C. Camp. 1959. Interview: Jack Leidig. Columbia College Oral History Series. Recorded 17 May 1959. Available at: http://apps.gocolumbia.edu/oralhistory/listen?96\&t=yosemite\&i=All\&a=Al 1\&p=0,Yosemite National Park Archives, El Portal, CA. (accessed January 3, 2017).

Heady, H. F. and P.J. Zinke. 1978.Vegetational changes in Yosemite Valley. National Park Service Occasional Paper, no. 5. Washington, DC: Department of the Interior. 
Huber, N. K. and J. Snyder. 2007. A history of the El Capitan moraine. In Yosemite Association, Geological Ramblings in Yosemite. California: Yosemite National Park, pp. 103-110.

Kinoshita, J. 2008. A legacy of fire: Looking back to look forward in Yosemite Valley. Yosemite, 70(2): 7-9.

Kuhn, B. and B. Johnson. 2008. Status and trends of black oaks (Quercus kelloggii) Populations and recruitment in Yosemite Valley (a.k.a. preserving Yosemite's oaks). Final report prepared for the Yosemite Fund. National Park Service, Yosemite National Park, Yosemite, CA. Available at: www.nps.gov/yose/learn/ nature/upload/Status-Trends-Black-Oaks-2008.pdf, (accessed December 14, 2016).

Long,J.W., M. K.Anderson, L. Quinn-Davidson, R.W. Goode, F. K. Lake, and C. N. Skinner. 2016. Restoring California black oak ecosystems to promote tribal values and wildlife. General Technical Report. U.S. Department of Agriculture, Forest Service, Pacific Southwest Research Station, Albany, CA.

Mancillas, S. 2000. When the rocks came down. A history of the Indians of Yosemite Valley, 1916-1953. Unpublished Master of Arts thesis, Department of History, Sacramento State University, Sacramento.

Martin, G. 1996. Keepers of the oaks. Discover Magazine August. Craig Bates Collection (Box 2, Folder 68). El Portal, CA: Yosemite Archives.

Matthes, F. E. 1930. Geologic history of the Yosemite Valley. U. S. Geological Survey Professional Paper \#160. USDI Geological Survey. Washington, DC: U.S. Government Printing Office..

McCarthy, H. n.d. Field guide to plants important to the Central Sierra Me-Wuk Indians with traditional uses, edited by T. Norton.

Milestone, J. F. 1978. The influence of modem man on the stream system of Yosemite Valley. Unpublished MA thesis. Department of Geography, San Francisco State University.

Moore, E. 1985. The eternal acorn: An ethnoarchaeological perspective. Unpublished Anthropology Paper for University Course (no university identified, possibly UCLA). On file, Anthropology Office, RMS. El Portal, CA: Yosemite Archives.

NFR (North Fork Rancheria of Mono Indians). 2019. Nikwa Nim (We are the people). In Voices of the People: The Traditionally Associated Tribes of Yosemite National Park. National Park Service, Yosemite National Park, pp. 1-19.

NPS (National Park Service). 2014. Notes taken atYosemite Forum: Kat Anderson Talk, December 9, 2014. Yosemite National Park, California. On file in the Anthropology Office, RMS, Yosemite National Park.

NPS (National Park Service). 2016a. Meeting notes from Fourteenth Annual All-Tribes Meeting. Draft 1, June 30, 2016, Yosemite East Auditorium, Yosemite National Park, California. On file in the Anthropology Office, RMS, Yosemite National Park.

NPS (National Park Service). 2016b. Meeting notes from tribal meeting and site visit to discuss Black Oak Research Project with Dr. Douglas Deur. Draft 2, October 18, 2016 Yosemite East Auditorium, Yosemite National Park, California. On file in the Anthropology Office, RMS, Yosemite National Park.

NPS (National Park Service). 2016c. Meeting notes from Tribal Meeting to discuss Black Oak Research Project with Dr. Douglas Deur. Draft 2. October 21, 2016, American Indian Council of Mariposa County Headquarters, Mariposa, California. On file in the Anthropology Office, RMS, Yosemite National Park.

NPS (National Park Service). 2016d. Meeting notes from Tribal Meeting to discuss Black Oak Ethnographic Research Project with Dr. Douglas Deur. Draft 3. March 17, 2016, Yosemite Resources Management Science Building, El Portal, California. On file in the Anthropology Office, RMS, Yosemite National Park.

NPS (National Park Service). 2019. Yosemite NP (YOSE) Reports, Annual Park Recreation Visitation (1906-Last Calendar Year), National Park Service Visitor Use Statistics. Available at: https://irma. nps.gov/Stats/SSRSReports/Park\%20Specific\%20Reports/Annual\%20Park\%20Recreation\%20 Visitation\%20(1904\%20-\%20Last\%20Calendar\%20Year)?Park=YOSE (accessed 25 October 2019).

Ortiz,B.R. 1991. ItWill Live Forever: TraditionalYosemite Indian Acorn Preparation. Berkeley, CA: Heyday Books.

Pfeiffer, J. M. and E. H. Ortiz. 2007. Invasive plants impact California native plants used in traditional basketry. Fremontia 35(1): 7-13.

Reynolds, R.D. 1959. Effect of natural fires and aboriginal burning upon the forests of the Central Sierra Nevada. Master's thesis, Department of Geography, University of California, Berkeley.

Rothman, H. K. 2005. A Test of Adversity and Strength: Wildland Fire in the National Park System. Washington, DC: National Park Service, U.S. Department of the Interior.

Spence, M. D. 1999. Dispossessing the Wilderness: Indian Removal and the Making of National Parks. Oxford: Oxford University Press.

SSM-AICMC (Southern Sierra Miwuk Nation). 2019. Reflections on the past, visions for the future. In Voices of the People: The Traditionally Associated Tribes of Yosemite National Park. El Portal, CA: National Park Service, Yosemite National Park, pp. 21-51. 
Stevens, M. 1998. The ethnobotany and distribution of white root (Carex barbarae). Folder 145, Box 3, Craig Bates Collection. El Portal, CA: Yosemite Archives.

Stewart, O. C. 2002. Forgotten Fires: Native Americans and the Transient Wilderness. Norman, OK: University of Oklahoma Press.

Storer, T. I. and R. L. Usinger. 1963. Sierra Nevada Natural History: An Illustrated Handbook. Berkeley, CA: The Regents of the University of California Press.

Stoy, W. H. 1890. Letter to the Honorable Secretary of the Interior. Biennial Report of the Commissioners to Manage the Yosemite Valley and the Mariposa Big Tree Grove for the Years 1889-90, 25-27. In Reports of the Commissioners to Manage the Yosemite Valley and the Mariposa Big Tree Grove for the Years, Biennial Reports 1889-1904-1888. Sacramento, CA: State Office.

Taylor, A. H. 2006. Fire History of Yosemite Valley. Final report for the Yosemite Fund through cooperative agreement 1443CA309701200 between the National Park Service and the Pennsylvania State University. On file. El Portal, CA: Yosemite RMS Library.

TBMI (Tuolumne Band of Me-Wuk Indians). 2019. Background and historic overview. In Voices of the People: The Traditionally Associated Tribes of Yosemite National Park. El Portal, CA: National Park Service, Yosemite National Park, pp. 147-185.

Turek, M. F. and R. H. Keller. 1998. American Indians and National Parks. Tucson, AZ: University of Arizona Press.

Vasquez, I. A. 2019. Evaluation of restoration techniques and management practices of Tule pertaining to eco-cultural Use. MS thesis, Humboldt State University.

West, L. 1986. The demise of Yosemite Valley's evergreens. Yosemite, 48(4): 2.

Wickstrom, C. K. R. 1987. Issues Concerning Native American use of fire: A literature review. Yosemite Research Center, Yosemite National Park, National Park Service, U.S. Department of the Interior.

YNP (Yosemite National Park). 2010. Scenic Vista Management Plan for Yosemite National Park. Environmental Assessment, July 2010. Yosemite National Park, National Park Service, U.S. Department of the Interior. Available at: www.nps.gov/yose/learn/management/upload/SVMP_YOSE_EA.pdf, (accessed 29 October 2019).

YNP (Yosemite National Park). 2011. 2010 Assessment of Meadows in the Merced River Corridor, Yosemite National Park. Resources Management and Science, Yosemite National Park, National Park Service, Department of the Interior.

YNP (Yosemite National Park). 2014. Merced Wild and Scenic River Final Comprehensive Management Plan and Environmental Impact Statement. National Park Service, U.S. Department of the Interior. 